\title{
Lithostratigraphy and Sequence Stratigraphy of Ultra-Deep E-Field, Eastern Niger Delta: Reservoir, Geological and Biostratigraphical Evidence
}

\author{
Matthew O. Akpan ${ }^{1}$ Paul A. Udofia ${ }^{2}$ Thomas A. Harry ${ }^{2}$ \\ 1.Department of Geology, University of Port Harcourt, Port Harcourt, Nigeria \\ 2.Department of Geology, Akwa Ibom State University of Science and Technology, Ikot Akpaden, Nigeria
}

\begin{abstract}
The ultra-deep offshore, eastern Niger Delta is marked by rapid, cyclic deposition of thick units of siliciclastic sediments ranging from deep marine to non-marine environments, deposited into rapidly subsiding sub-basins occurring along the slope of the continental margin. This rapid deposition resulted in thick third-order sequences and systems tracts. Patterns of deposition were analysed from seismic reflection configuration and well-log patterns. Lithofacies patterns critical for systems tract recognition were interpreted from well logs and tied to seismic sections where possible. Sediment accumulation plots were constructed and employed to interpret the location of stratigraphic condensation, key surfaces, diffuse boundaries between systems tracts and evaluate the significance of condensed sections. The origin of these condensed sections is caused by major allocyclic changes associated with transgression and shifting of the deltaic depocenter that fed the area. The regional change in condensation through time was interpreted as reflecting avulsion of the shallow marine sediment source. The compilation of sediment accumulation plots also showed a major increase in sedimentation approximately 2.4 Ma; caused by the influx of the prograding shallow marine sediments. Wells located in distal regions in this field are more condensed [steeper slope] than proximal locations. The resulting analyses of this study showed that the basin-floor fan has the highest rate of deposition and could be identified as a gentle slope in the line of sediment accumulation. In the distal regions of the field, TST's are characterized by sediment starvation because most of the sediments are trapped in the proximal areas. The maximum flooding surfaces [MFS's] were recorded in deep water as condensed sections. Secondary condensed sections were delineated and interpreted to have deposited above the top basin-floor fan surface [tbfs] and top slope fan surface [tsfs]. In addition to traditional first downhole occurrence biostratigraphy, the database also contains information on nannofossil abundance. The sands encountered in the reservoirs are correlatable indicating a relatively longer period of depositional cycle.
\end{abstract}

Keywords: Lithostratigraphy, Sequence stratigraphy, Eustacy, Reservoir geology, Biostratigraphy, Ultra-deep Offshore, Eastern Niger Delta.

DOI: $10.7176 / \mathrm{JEES} / 10-7-06$

Publication date:July $31^{\text {st }} 2020$

\subsection{Introduction}

There is a wide spectrum of bottom currents, for example, the bottom currents sensu stricto (contour currents) that operate in deep water such as in the E-Field of the Niger Delta. These currents are those that are part of either the thermohaline- or wind-driven major circulation patterns. Such currents generally have an overall alongslope flow, but in detail their velocity and direction are extremely variable in both time and space. In fact they are affected by seafloor morphology (obstacles, gateways, and changes in slope direction and steepness), Coriolis force, circular motions (gyres and eddies) unrelated to contours, and eddy kinetic energy changes (seasonal and at different scales). Additional types of deep (bottom) currents not driven by sediment suspension have been observed to flow mostly perpendicular to the slope. These include currents related to internal waves and tides (formed between subsurface water layers of varying density), canyon currents (frequently reversing flow of clear or very low-density turbid waters), down- and up- welling flows (currents on the continental slopes that may be generated by density, wind, storms, or obstructions).

Hydrocarbon-filled sandstones in this field were easily identified on well logs and seismically represented by high amplitude reflection events. The excellent reservoir characteristics evaluated are probably a consequence of several factors such as: their quartz-dominated mineralogy, long residence in mildly over-pressured environments that probably limit diagenetic effects, their early hydrocarbon charge in a multi-source and evaporativefractionated petroleum system that has been generating and pooling hydrocarbons since, at least, the Neogene (e.g., Bruso and Wallace, 2004).

Most known traps in this field are both structural and stratigraphic. The structural traps developed during synsedimentary deformation of the Agbada paralic sequence (Evamy et al. 1978, Stacher et al. 1993, Stacher, 1995, Krusi and Idiagbor, 1994). Structural complexity increases from the north (earlier formed depobelts) to the south in response to increasing instability of the under-compacted, over-pressured shale. In this field, hydrocarbons have been found in traps involving: doubly plunging downthrown anticlines in growth fault expanded sandstone 
reservoirs and fault-juxtaposed over-pressured shales in their contiguous downthrown blocks. Fault-juxtaposed over-pressured shales have sealed hydrocarbon accumulations laterally. The major bounding faults act as migration conduits that feed deeply sourced hydrocarbons into shallower shale - sealed reservoirs. Figures 1 and 2 illustrate typical petroleum deposit schemes in which oil and gas are generated at the source, migrate in direction of least resistance and are subsequently trapped and accumulated to form petroleum reservoirs in the study area. Migration has probably occurred along and across the field basal unconformity, especially where deeply incised submarine canyon walls separate over-pressured field sediments within the canyon from Akata Formation sediments that form the canyon's walls.

In this study, biofacies analyses were used in conjunction with facies interpretation derived from seismic and well log studies. In this deep-water setting, significant condensed sections developed during deposition of the transgressive and highstand systems tracts (including the maximum - reveals that the seismic loop was good to be associated with separate hydrocarbon plays). Major condensed sections in the field span four depositional sequences (e.g., 6.3, 5.5, 4.2, 3.0 and 2.6 Ma). The compilation of sediment accumulation plots from nine wells in the study area indicates two different condensed sections. The origin of these condensed sections is probably caused by major allocyclic changes associated with a regional transgression and shifting of the deltaic depocenter that fed the area (e.g., Pulham, 1993, Weimer et al. 1998, Villamil et al. 1998). The maximum flooding surfaces (MFS's) in this study were recorded in deep water as condensed sections. The transgressive and the highstand systems tracts are represented by a single, condensed section. Additionally, the regional change in condensation through time was interpreted as reflecting avulsion of the shallow marine sediment source.

\subsection{Physiographic setting}

The field strata occupy a broad section in the Offshore Depobelt, from the continental shelf to slope break extending to the ultra deep waters and are located in the eastern Niger Delta, Nigeria, where thick late Cenozoic clastic sequences of Agbada Formation were deposited in a deltaic fluvio-marine environment (Figure 1). The reservoirs of the E-Field complex occur in debris flow and slump sandstones of the Qua Iboe Formation (e.g. Snedden et al., 1994); comprising large, channelized sandbodies deposited in deep water settings (Figure 4). This study focuses on deep areas of this field, which hold potential, particularly within large fan-like mound features recognized on seismic data in front of the toe-thrust limit, which are yet untested for drilling.

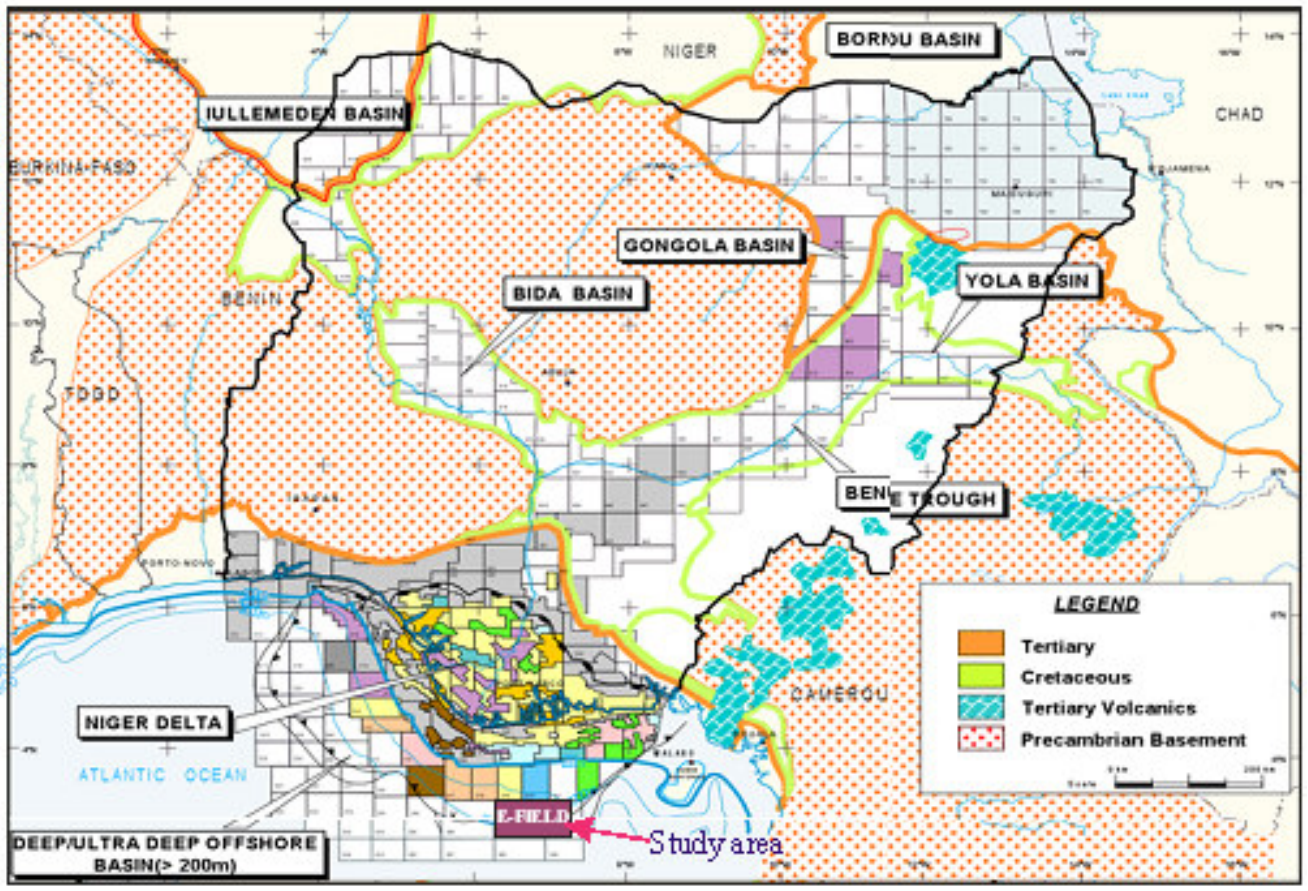

Fig. 1: Nigerian Sedimentary Basins and Leases

\subsection{Methods}

Basic well data employed for this study include well logs, seismic reflection profiles, biostratigraphic ages and depositional environments. The eustatic cycle changes, synthetic seismograms and seismic data were interpreted using sequence stratigraphic concepts to validate the well-to-seismic ties. Seismic interpretation has been based on: the analysis of the lateral termination of the reflectors (onlap, downlap, erosional truncation - Figure 5) according to the general concepts of seismic stratigraphy (Vail and Mitchum, 1991), the seismic facies 
characteristics and the correlation of distinctive reflectors between profiles.

Depositional patterns were analysed from seismic reflection configurations and well log signatures. Log patterns, in this study, were observed on gamma-ray logs, but similar conclusions were also drawn from neutrondensity logs and, in some cases, from resistivity logs (Figure 2). In general, the wells in the study area show clastic regressive successions with sand predominating. They are made up of alternating sand and shale including appreciable siltstone. The sand/shale ratio increases progressively towards the base of the studied interval as seen from the logs of the well sections in Figure 2. The formation consists mostly of beach/shoreface and channel sands with minor shales in the upper part, regressive barrier bar, tidal channels and shales in the middle part, and alternation of sands and shales in approximately equal proportion in the lower part.

Lithofacies patterns critical for systems tract recognition were interpreted from well logs and tied to seismic sections where possible. Depositional sequences were interpreted and sub-divided into a succession of systems tracts, each of which was interpreted to have deposited during a specific phase or portion of a cycle of relative change of sea level. A few key seismic lines were biostratigraphically tied to the available well control in order to provide adequate information for well logs and seismic sequence stratigraphic analyses. The data available for paleo-bathymetric interpretation were obtained from benthic foraminifers recorded on high-resolution biostratigraphic checklists (Figure 3). Identification of the maximum flooding surfaces (MFS's) and its associated depositional facies, the condensed sections, through the analysis of faunal and floral abundance/diversity data obtained from the detailed stratigraphic distribution charts permits sub-division of E-logs and seismic record sections into a series of sediment packages that are bounded by chronostratigraphic surfaces. Here, condensed sections were identified and located on well logs based on faunal and floral abundance and diversity to recognize warm water condensed sections associated with MFS's, cold water condensed sections associated with the top slope fan surface [tsfs] and basin-floor fan surface [tbfs] and minor condensed sections between channel overbank lobes in slope fan complexes.

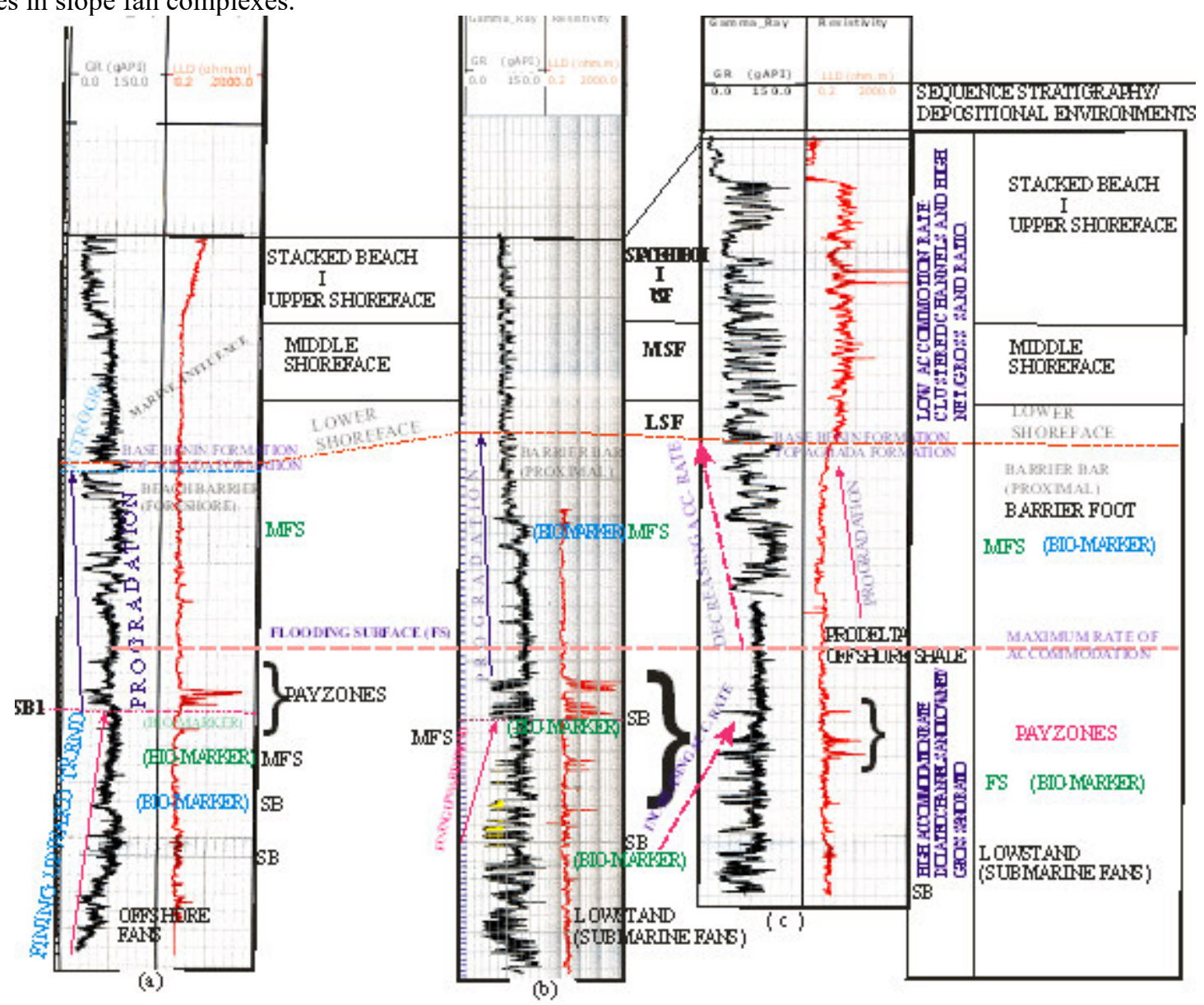

Fig. 2: Observed log patterns of Sequence Boundaries, Well Markers and Pay zones 


\begin{tabular}{|c|l|l|l|l|l|}
\hline Depth $(\mathbf{m})$ & \multicolumn{1}{|c|}{ Bio-Markers } & Occurrence & Species Type & Age (Ma) & $\begin{array}{c}\text { Sequence } \\
\text { Surface } \\
\text { Indicated }\end{array}$ \\
\hline 700 & M. costata & & & & \\
\hline & & & & & FDO \\
\hline 1060 & S. abies & FDO & Nanno & 3.2 & Near SB300 \\
\hline & & & & & \\
\hline 1125 & S. pseudoumbilica & FDO & Nanno & 3.3 & Near MFS340 \\
\hline & & & & & \\
\hline 1760 & U. rustica & FDO & Foram Benthic & 4.2 & SB420 \\
\hline & & & & & \\
\hline 1775 & V. flexilis & FDO & Foram Benthic & 5.0 & MFS500 \\
\hline & T. parvula & FDO & Foram Benthic & 5.0 & MFS500 \\
\hline & & & & & \\
\hline 2230 & D. quinqueramus & FDO & Nanno & 5.6 & Near SB550 \\
\hline & & & & & \\
\hline
\end{tabular}

FDO (First Downhole Occurrence) = Local LAD (Local Stratigraphic Last Appearance Datum)

Figure 3a: B io-markets recovery in wells of the E-field, Niger Delta (E1f Nig. Ltd., 2006).

\begin{tabular}{|c|c|c|c|c|c|c|c|}
\hline \multirow{2}{*}{$\begin{array}{l}\text { DEPTH(m) } \\
875\end{array}$} & \multicolumn{2}{|c|}{$\begin{array}{l}\text { ELSTRATGRAPHYMEI C] } \\
\text { Bio-m arkers Recovery/sequence } \\
\text { surfaces and Age indicated. }\end{array}$} & \multirow{2}{*}{$\begin{array}{l}\text { TMME } \\
\text { [Seconds] } \\
0.950\end{array}$} & \multirow{2}{*}{$\begin{array}{l}\text { DEPTH(m) } \\
700\end{array}$} & \multicolumn{2}{|c|}{ 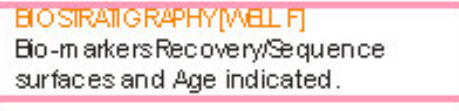 } & \multirow{2}{*}{$\begin{array}{l}\text { TMEE } \\
\text { [Sec ond s] } \\
0.700\end{array}$} \\
\hline & Tmexicana [田] & $S 82.4 \mathrm{Ma}$ & & & M.costata [FB] & MFS2.45Ma & \\
\hline 1060 & M.costata [ [ & $\mathrm{MFS} 2.45 \mathrm{Ma}$ & 1.005 & 1060 & S abies [N] & 3.2Ma[Near & 1050 \\
\hline 1720 & Sabies $[N]$ & so $3.0 \mathrm{Ma}$ & 1.700 & & Spsudoumb & 3.3Ma[Near & \\
\hline 1725 & S pseudoumbilica [N] & $\begin{array}{l}\text { 3.3M a [Nèar } \\
3.4 \mathrm{Ma} \text { ] }\end{array}$ & 1.705 & 1760 & 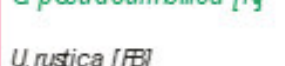 & $3.4 \mathrm{Ma}$ a] & 1.120 \\
\hline 1860 & U.rustica [用] & $584.2 \mathrm{Ma}$ & 1.805 & 1775 & & & 1.000 \\
\hline 1875 & V. flexis $/ T$ parvula [rB] & MFS5.0Ma & 1.813 & 2230 & D. quinqueramus[ $[N]$ & $\begin{array}{l}\text { 5.6Ma[Near } \\
\text { Fs.5Ma] }\end{array}$ & 2.005 \\
\hline 2175 & D. quinqueramusin $\mathbb{N}$ & {$[\mathrm{H} 6.5 \mathrm{Ma}]$} & 2.025 & & & & \\
\hline
\end{tabular}

Figure 3b: Biomarkers Recovery/Sequence Surfaces and their ages

\subsection{Results and discussion}

\subsection{Reservoir geological evidence}

Based on the qualitative and quantitative interpretations, nine (9) producible reservoirs were identified. These hydrocarbon-bearing reservoirs were easily identified and located within depths of $1625 \mathrm{~m}$ to $1875 \mathrm{~m} ; 1575 \mathrm{~m}$ to $1625 \mathrm{~m} ; 1512.5 \mathrm{~m}$ to $1650 \mathrm{~m} ; 1537.5 \mathrm{~m}$ to $1587.5 \mathrm{~m} ; 1800 \mathrm{~m}$ to $2000 \mathrm{~m} ; 2363.5 \mathrm{~m}$ to $2475 \mathrm{~m} ; 1762.5 \mathrm{~m}$ to $2125 \mathrm{~m}$; $1625 \mathrm{~m}$ to $1775 \mathrm{~m} ; 1900 \mathrm{~m}$ to $2162.5 \mathrm{~m} ; 1675 \mathrm{~m}$ to $1900 \mathrm{~m} ; 1725 \mathrm{~m}$ to $1775 \mathrm{~m}$ and $1889.5 \mathrm{~m}$ to $1925 \mathrm{~m}$. The computed petrophysical parameters of some of those reservoirs are shown in table 1 below. 
TABLE 1: COMPUTED PETROPHYSICAL PARAMETERS OF E-FIELD RESERVOIRS. Average Number of Reservoirs $=$ Nine (9).

\begin{tabular}{|c|c|c|c|c|c|c|c|c|c|c|c|}
\hline $\begin{array}{c}\text { WELL } \\
\text { NO/ } \\
\begin{array}{c}\text { RESERV. } \\
\text { SAND. }\end{array}\end{array}$ & $\begin{array}{c}\text { TOP(md) } \\
\text { M (ft) }\end{array}$ & $\begin{array}{c}\text { TIME } \\
(\mathrm{Sec})\end{array}$ & $\begin{array}{c}\text { BOTTOM } \\
(\mathrm{md}) \\
\mathrm{M}(\mathrm{ft})\end{array}$ & $\begin{array}{c}\text { TIME } \\
(\mathrm{Sec})\end{array}$ & $\begin{array}{c}\text { Th(sd+sh) } \\
(\mathrm{GROSS}) \\
\mathrm{M}(\mathrm{ft})\end{array}$ & $\begin{array}{c}\text { Th(sd) } \\
(\mathrm{NET}) \\
\mathrm{M}(\mathrm{ft})\end{array}$ & $\begin{array}{c}\text { NET/ } \\
\text { GROSS } \\
(\mathrm{NTG})\end{array}$ & $\varnothing$ & $\emptyset_{\mathrm{e}}$ & $\mathrm{V}_{\mathrm{CL}}$ & $\mathrm{SW}$ \\
\hline $\mathrm{AI} / \mathrm{ER}-1$ & $\begin{array}{c}1625 \\
(5245.7)\end{array}$ & 1.575 & $\begin{array}{c}1875 \\
(6151.9)\end{array}$ & 1.775 & $\begin{array}{c}250 \\
(820.25)\end{array}$ & $\begin{array}{c}175 \\
(574.2)\end{array}$ & 0.700 & 0.18 & 0.16 & 0.13 & - \\
\hline $\mathrm{A} / \mathrm{ER}-2$ & $\begin{array}{c}1550 \\
(5085.6)\end{array}$ & 1.463 & $\begin{array}{c}1625 \\
(5245.7)\end{array}$ & 1.600 & $\begin{array}{c}75 \\
(246.08)\end{array}$ & $\begin{array}{c}37.5 \\
(123.1)\end{array}$ & 0.500 & 0.18 & 0.13 & 0.20 & - \\
\hline B/ER-3 & $\begin{array}{c}1512.5 \\
(4962.5)\end{array}$ & 1.463 & $\begin{array}{c}1712.5 \\
(5618.7)\end{array}$ & 1.638 & $\begin{array}{c}200 \\
(656.2)\end{array}$ & $\begin{array}{c}62.5 \\
(205.1)\end{array}$ & 0.313 & 0.35 & 0.31 & 0.20 & - \\
\hline C/ER-4 & $\begin{array}{c}1537.5 \\
(5044.5)\end{array}$ & 1.475 & $\begin{array}{c}1600 \\
(5249.6)\end{array}$ & 1.600 & $\begin{array}{c}62.5 \\
(205.1)\end{array}$ & $\begin{array}{c}62.5 \\
(205.1)\end{array}$ & $1.000 ?$ & 0.30 & 0.21 & 0.20 & 0.024 \\
\hline D/ER-5 & $\begin{array}{c}1812.5 \\
(5946.8)\end{array}$ & 1.650 & $\begin{array}{c}2425 \\
(7956.4\end{array}$ & 2.075 & $\begin{array}{c}612.5 \\
(2009.6)\end{array}$ & $\begin{array}{c}176 \\
(577.5)\end{array}$ & 0.287 & & & 0.08 & - \\
\hline E/ER-6 & $\begin{array}{c}1762.5 \\
(5782.8)\end{array}$ & 1.663 & $\begin{array}{c}1950 \\
(6398)\end{array}$ & 1.813 & $\begin{array}{c}187.5 \\
(615.19)\end{array}$ & $\begin{array}{c}112.5 \\
(369.1)\end{array}$ & 0.600 & 0.22 & 0.21 & 0.13 & 0.0284 \\
\hline F/ER-7 & $\begin{array}{c}1625 \\
(5331.6)\end{array}$ & 1.550 & $\begin{array}{c}2112.5 \\
(6781.13)\end{array}$ & 1.913 & $\begin{array}{c}487.5 \\
(1599.5)\end{array}$ & $\begin{array}{c}375 \\
(1230)\end{array}$ & 0.769 & 0.31 & 0.29 & 0.14 & 0.0232 \\
\hline G/ER-8 & $\begin{array}{c}1675 \\
(5495.7)\end{array}$ & 1.625 & $\begin{array}{c}1887.5 \\
(6192.9)\end{array}$ & 1.788 & $\begin{array}{c}212.5 \\
(697.2)\end{array}$ & $\begin{array}{c}100 \\
(328.1)\end{array}$ & 0.4706 & 0.35 & 0.31 & 0.22 & - \\
\hline H/ER-9 & $\begin{array}{c}1725 \\
(5659.7)\end{array}$ & 1.663 & $\begin{array}{c}1925 \\
(6315.9)\end{array}$ & 1.825 & $\begin{array}{c}200 \\
(656.20\end{array}$ & $\begin{array}{c}113.5 \\
(372.4)\end{array}$ & 0.5675 & 0.20 & 0.17 & 0.14 & - \\
\hline
\end{tabular}

The interpreted reservoir parameters in this field were compared to the reservoir parameters of some deep water wells in Nigeria, as shown in Table 2.

Lowstand fans (i.e.; basin floor fan, slope fans and a variety of ramp geometries) exist containing reservoir sands deposited by various gravity-flow (turbidites-related) processes (Leeder, 2001, Hughes, 2000). Here, basin floor fan is the most obvious reservoir but stratigraphic trapping is more common in the smaller individual sand bodies observed within the more shale-prone slope fans. Further, petroleum occurs in coarse-grained turbidity deposits in this field located between shale diapiric structures. The reservoir is located within depths of $1800 \mathrm{~m}$ to $2000 \mathrm{~m}$, and $2362.5 \mathrm{~m}$ to $2475 \mathrm{~m}$. The gross and net thicknesses of this reservoir are $612.5 \mathrm{~m}(2009.6 \mathrm{ft})$ and $176 \mathrm{~m}$ (577.5ft), respectively. The average porosity (Ø) of these reservoirs, which is 0.386 or $38.6 \%$, was calculated from neutron, density and sonic logs (refer to table 1).

Table 2: Reservoir parameters of some deep water wells in Nigeria

Key parameters of the reservoirs include:

\begin{tabular}{|c|c|}
\hline Average Number of Reservoirs & 5 \\
\hline Porosity & $18-35 \%$ \\
\hline Permeability & $2120-2940 \mathrm{mD}$ \\
\hline Net to Gross & $20-45 \%$ \\
\hline Average Closure area & $230 \mathrm{~km}^{2}$ \\
\hline Average Net Pay & $88.5 \mathrm{~m}$ gas, $75 \mathrm{~m}$ oil. \\
\hline Reservoir Pressure (Psi) & $4000-5600$ \\
\hline Bubble Point Pressure & $3000-5100$ \\
\hline Playtype & Stratigraphic/Structural. \\
\hline API Gravity & $29-31^{\mathbf{0}}$ \\
\hline STOIIP per field MMstb & $1156-2415$ \\
\hline Gas - Oil -ratio scf/bbl & $325-1420$ \\
\hline Overall reservoir Quality & Excellent \\
\hline
\end{tabular}

\subsection{Biostratigraphical evidence}

The biostratigraphic / paleobathymetric reports of wells (Figure 7a-b) were available for mapping and interpreting the first appearance or inception (FAD) and the last appearance or extinction (LAD) of a fossil species in the rock record and to establish useful markers for biostratigraphic correlation. In addition to traditional first downhole occurrence biostratigraphy, the database also contains information on nannofossil abundance. Nannofossil abundance data had been used with traditional biostratigraphy in the interpretation of the paleoenvironment, in depicting regional stratigraphic trends, and in generating the chronostratigraphy of the region.

The shifts in the water mass and circulation patterns associated with eustatic variations had profound effects on the foraminiferal distribution patterns in the study area. Biofacies analyses were used in conjunction with facies interpretations derived from seismic and well logs studies. The E-Field depositional configuration is strongly 
influenced by tectonic activities of the Miocene-Pliocene Epochs.

In the E-Field, the important morphological elements are the offshore depozone, the shoreface depozonedivided into the lower, middle and upper zone and the foreshore depozone. The depozones of the "foreshoreshoreface-offshore" model of Walker and Plint, 1992 can be filled with various depositional elements that were identified by the lithofacies and ichnofacies analyses. (Harry et al, 2018)

In the study area, shoreface depozone ranges between the fair-weather-wave-base [FWWB] and the low tide line, while the morphological gradient decreases offshore. The lower shoreface is transitional between the middle shoreface and the offshore zone. The offshore zone is characterized by fine clastic sedimentation under lowenergetic hydrodynamic conditions below the fair- weather-wave-base [FWWB]. The shale lithofacies is representative of this depozone and effected by high-energetic conditions only during storm, cut during the lowstand when rivers reach out to the shelf, as sea level rises estuaries are filled by a complex pattern of sand and mud packets, broken by several recognizable surfaces, a transgressive surface, a maximum flooding surface and local ravinement surfaces caused by tidal or wave action (e.g., Zaitlin et al., 1994).

\subsection{Sediment Accumulation Plots and Sequence Stratigraphy}

Villamil et al., 1998 postulate that sediment accumulation plots can help interpret the location of stratigraphic condensation, key surfaces, diffuse boundaries between systems tracts, and to evaluate the regional significance of the condensed sections. In this study, sediment accumulation plots were constructed by plotting all LAD's from a well so that absolute geologic time is on the vertical axis and stratigraphic thickness is on the horizontal axis (Table 3 and Figure 8). On the sediment accumulation plots, the line of correlation [LOC] was derived from cross plotting the theoretical position of microfossil extinctions or LAD in the 'absolute' time domain vs. the stratigraphic location of extinctions. According to Villamil et al. 1998, the slope of the different segments of the LOC constructed (Figure 8), reflects the history of sediment accumulation not de-compacted. Line segments with steep slopes represent relatively low sedimentation rates with small thickness accumulating during long periods. Gently sloping segments of the line represent periods of high accumulation rates, i.e., thick packages deposited during short periods. (Harry et al 2017)

Major condensed sections span four depositional sequences (6.3, 5.5, 4.2, 3.0 and 2.6 Ma) (Table 3 and Figure 8). In addition, the compilation of sediment accumulation plots from nine wells in the study area indicates two different condensed sections. The origin of this condensed section is caused by major allocyclic changes associated with a regional transgression and shifting of the deltaic depocenter that fed the area (Pulham, 1993; Weimer et al. 1998., Villamil et al. 1998). The regional change in condensation through time was interpreted as reflecting avulsion of the shallow marine sediment source. Additionally, the compilation of sediment accumulation plots shows a major increase in sedimentation about $2.4 \mathrm{Ma}$; caused by the influx of prograding shallow marine sediments.

Wells located in distal regions are more condensed [steeper slope] than proximal locations. The lowstand systems tract has been divided into three components: basin-floor fan, slope fan, and prograding complex (Vail, 1987, Mitchum et al., 1977., Mitchum et al., 1992). Here, results indicated that the basin-floor fan has the highest rate of deposition and could be identified as a gentle slope in the line of sediment accumulation. The slope fan and the prograding complex cannot be differentiated clearly and consistently from one another based on changes in the slope of the accumulation curve, probably because they are characterized by similar sedimentation rates, the lack of prograding complexes (i.e., deltas) in sequences older than $0.7 \mathrm{Ma}$, or because differentiating these two systems is beyond the resolution of present-day biostratigraphy, that is, there are not enough points on the line of correlation (e.g., Villamil et al., 1998). 
Table 3: Stratigraphic Positions of Chronostratigraphic Surfaces/LAD [expressed in 'absolute"timedomain] inthe Wells in Metres (m), E-Field.

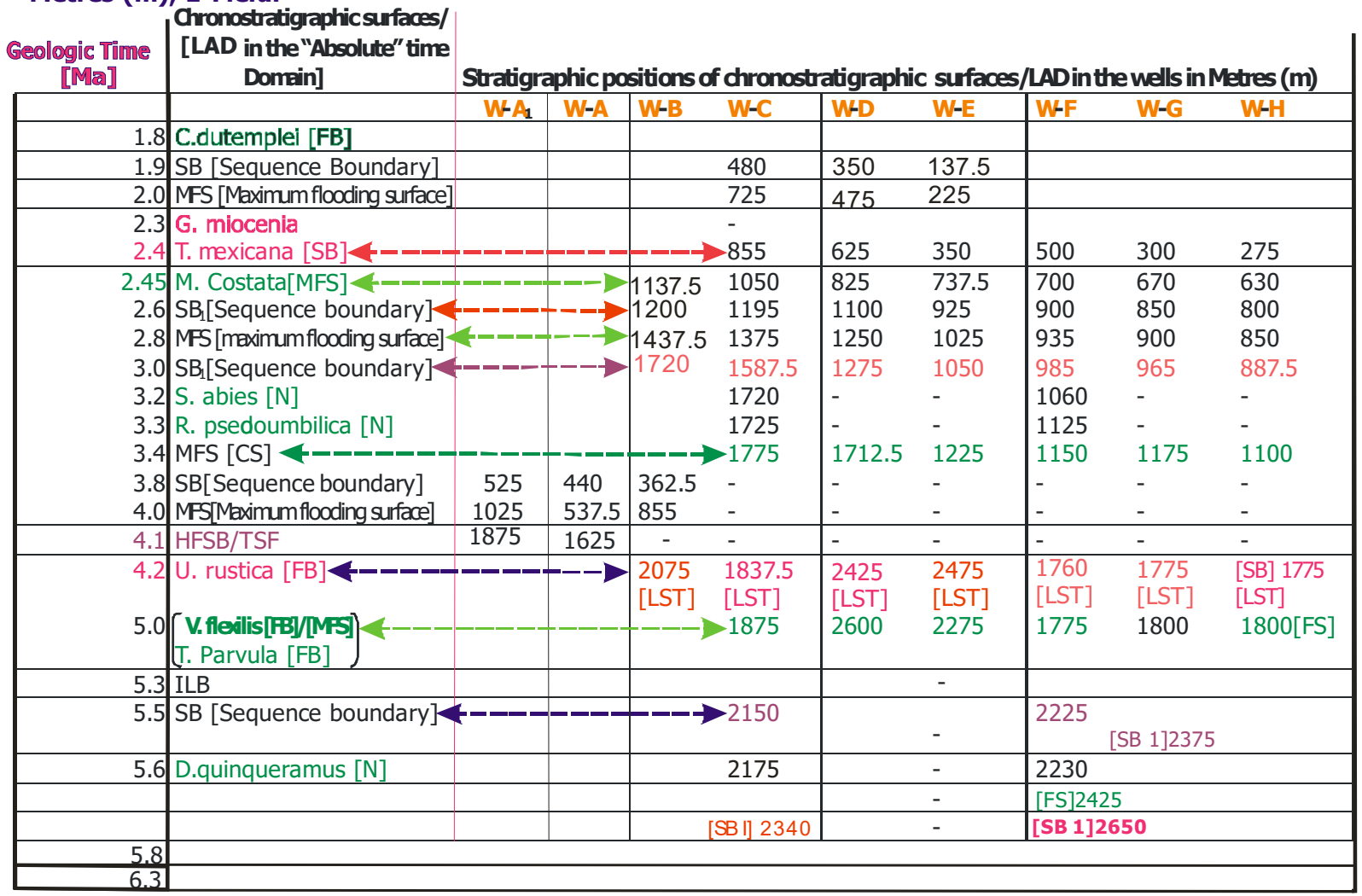

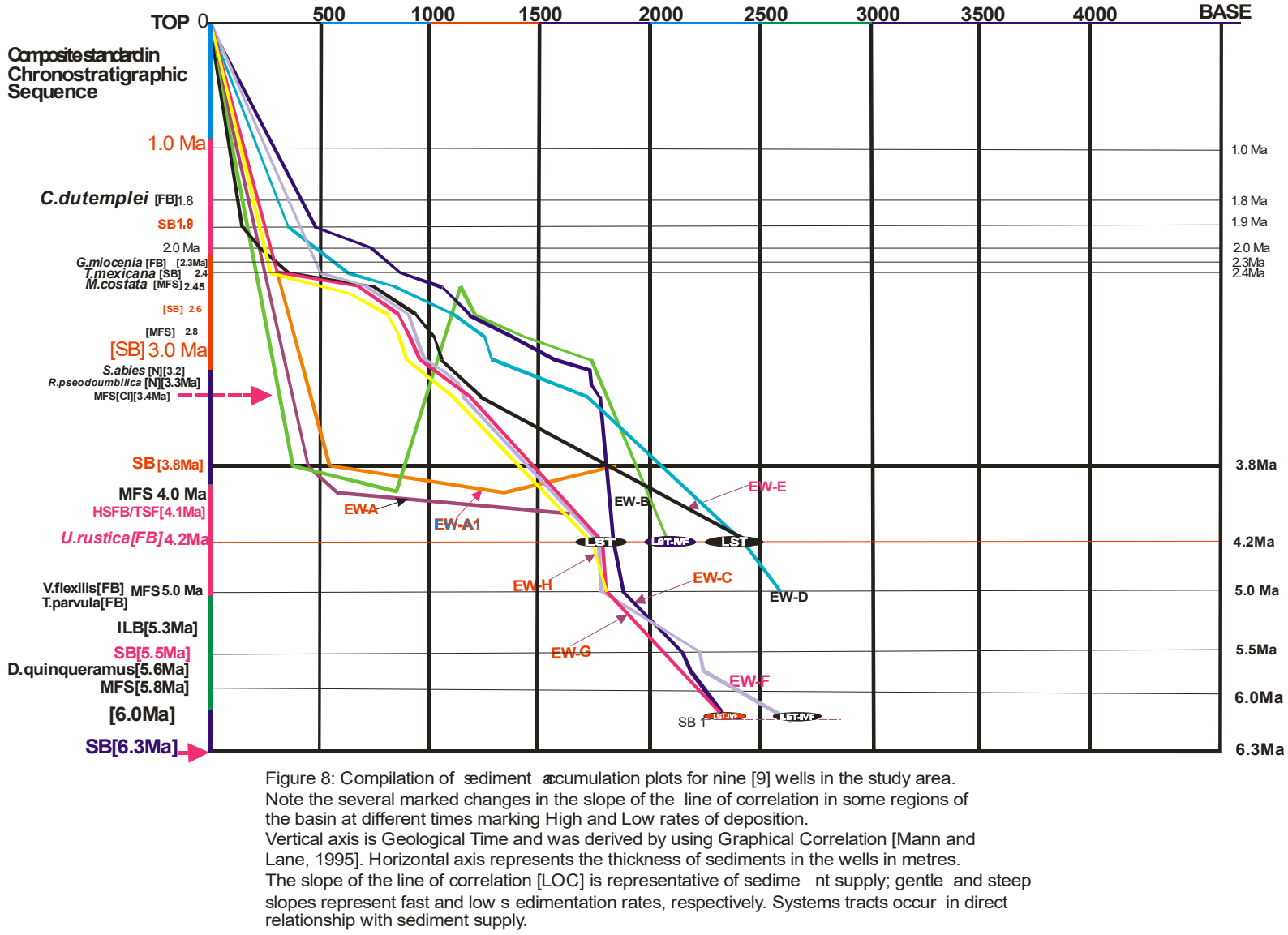


In distal regions of the E-Field, TST's are characterized by sediment starvation because most of the sediments are trapped in proximal areas. The micropaleontological data in the form of high-resolution biostratigraphy play a critical role in:

(i) Providing paleobathymetric data to relate the sediments and their contained microfauna to specific water depths at the time of deposition;

(ii) Recognizing and verifying the occurrence of condensed sections and whether they represent climatic cycles (warm and cold periods) that appear to coincide with the physically defined sequences; and

(iii) Dating condensed sections so that the locally recognized cycles, according to Vail and Wornardt 1991, can be correlated with the globally recognized cycles of the eustatic cycle chart of Haq et al., 1988. Key recognition criteria for condensed sections are the maximum abundance and diversity peaks that are generated from the microfaunal and microfloral checklists and dated in absolute time (millions of years, for example, Shaffer, 1987; Vail and Wornardt, 1991; Mulholland, 2003.

The discrimination of biofacies helps place the associated strata into depositional settings (Figure 9). Variations in the rates at which accommodation in this field increases resulted in three different types of parasequence stacking patterns [i.e.; transgressive, aggrading and regressive stacking patterns. Regional variations in tectonic subsidence in the study area modify the nature and patterns of the depositional sequences and the timing and nature of the key surfaces and systems tracts. These changes in fluvial accommodation modify the channel to floodplain ratio and are brought about by variations in relative sea level, tectonic subsidence or both.

The maximum flooding surfaces [MFS's] delineated in this field were recorded in deep water as a condensed section. Most MFS's form major stratigraphic surfaces associated with widespread shale deposits over the shelf, which form good regional markers and hydrocarbon seals. They represent the best potential for stratigraphic trapping because they contain isolated reservoirs and are overlain by regional shale seals. The transgressive and the highstand systems tracts were represented by a single, condensed section. A segment with a steep slope characterizes sedimentation rate. The sequence boundary [SB] marks the base of the lowstand systems tract and is marked by an abrupt change from low to high sedimentation rates. Seven abundance/diversity events correlate with regionally consistent bio-chrono events indicating possible candidates for maximum flooding surfaces. Of these, four [i.e. MFS 2.8 Ma, MFS 3.4 Ma, MFS 5.0 Ma and MFS 5.8 Ma] also consistently occur with high gamma-ray values and downlap surfaces-interpreted as CONDENSED SECTIONS. On the shelf to basin depositional profile, the condensed section ranges from a fossil-rich zone on the proximal shelf to a biostratigraphic gap in the basin.

In this study, intervals of fossil abundance occur that are regionally coeval. The change in the rate of sediment accumulation associated with lobe-abandonment in deltaic and submarine fan systems resulted in an interval of fine grained, fossil-rich sediments. These local abundance events, according to Armentrout et al. 1993, are called condensed intervals. Secondary condensed sections were delineated and interpreted to have deposited above the following surfaces:

i) Top basin-floor fan surface (tbfs), and

ii) Top slope fan surface (tsfs).

The slope fan and Lowstand Prograding Wedge downlap onto the top basin-floor fan surface (tbfs). The lowstand prograding wedge also downlaps on the top slope fan surface (tsfs). The top slope fan surface (tsfs) downlaps onto the basin floor fan or sequence boundary seaward and onlaps onto the top of the underlying depositional sequence landward.

\subsection{Conclusions}

Lithological and biostratigraphical studies of the E-Field have contributed to the sequence stratigraphic study of the area. The depositional environments in this field point to a fluvial, deltaic, shelf, slope, and deeper basin origin; and characterize the distribution of reservoir facies. Depositional environments interpreted include coastal deposits and prodelta sands, reworked sand units and shoreface sands, slope fan, basin floor fan and submarine fan environments. Reservoir and play significance of sedimentary systems such as incised fluvial valleys (IVF's), lowstand coastal sand deposits and submarine fans have been fully realized and practical guidelines for their exploration have been developed. These sedimentary systems occur in distal areas of the E-field, such as distal shelf environments, where prior thinking had concluded a lack of sand potential.

The paleo-geographic reconstruction using isopach map of the payzone thicknesses penetrated in some wells in this field has provided a greater insight for understanding of the paleo-river dynamics and its morphology. Synthetic seismogram as well as more biostratigraphic data for more wells in the E-Field should be studied effectively to help balance the discrepancies in results obtained between seismic and well data. More development wells programmed for this field could be sited on the down-thrown blocks because of the presence of juxtaposed over-pressured shales acting as seals to reservoirs and the trapping capacity of faults at this level - to enhance maximum hydrocarbon recovery. Finally, this study has opened new dimensions for identifying the prospective zones for future exploration in the E-Field. 


\section{Acknowledgements}

The author wishes to thank the management of Elf Producing Nigeria Unlimited for providing the subsurface information required for this study and the permission to publish the results. The management of the Geology Department, University of Port Harcourt is acknowledged for making available all the facilities needed at the workstation. My supervisor, Emeritus Professor Michael N. Oti is also acknowledged for his incisive comments and valuable contributions to this study. This research did not receive any specific grant from funding agencies in the public, commercial, or not-for-profit sectors.

\section{References}

AAPG UGM - SC. in American Association of Petroleum Geologists (database online). 2011 (cited 03/18 2014). Available from http:/ugmsc.wordpress.com/2011/03/30/one-day-course-review-hydrocarbon-prospect-inwestern-indonesia.

Armentrout, J. M; Malecek, S. J; Fearn, L. B; 1993: Log-motif Analysis of Paleogene Depositional Systems Tracts; Central and Northern North Sea: Define by Sequence-Stratigraphic Analysis: London Geological Society, P. $1-41$.

Bruso, J. M.(Jr); Getz, S. L; and Wallace, R. L; 2004: Exploration and Development. Gulf of Guinea's Golden Rectangle Geology. (Adapted from the February 16, Edition of Oil and Gas Journal). Penn Well Corporation. P. $1-8$.

Evamy, B. D., J. Haremboure, P. Kamerling, W. A. Knaap, F. A. Molloy, and P. H. Rowlands, 1978: Hydrocarbon Habitat of Tertiary Niger Delta: AAPG Bulletin, V. 62, P. $1-39$.

Harry, T., Bassey, C., Udofia P., Daniel, S, (2017): Baseline study of Estuarine Oceanographic Effects on Benthic foraminifera in Qua Iboe, Eastern Obolo and Uta Ewa/Opobo River Estuaries, Southeastern Nigeria. Vol. 8. 2017. 1422.

Harry, T.A, Etuk, S. E, Joseph, Okoli Austin (2018) Geomechanical evaluation of reservoirs in the coastal swamp, Niger delta region of Nigeria. 2018, 2018. 6(2): p. 8 .

Harry, T.A, Ushie, F.A, Agbasi, O. E (2018): Hydraulic and Geoelectric relationships of Aquifers Using Vertical Electrical Sounding (VES) in parts of Obudu, Southern Nigeria. Vol

Haq, B. U; Hardenbol, J; and Vail, P. R; 1988: Mesogeic and Cenozoic Chronostratigraphy and eustatic cycles of sea-level charge: In: Wilgus, C. K; Hastings, B. S; Kendall, C. G. St. C; Posamentier, H. W; Ross, C. A; and Van Wagoner, J. C; eds; Sea-level Changes - An Integrated Approach: Society of Economic Paleontologists and Mineralogists Special Publication. No. 42, P. $71-108$.

Hughes, T; 2000: Reservoir Sedimentology and Sequence Stratigraphy in an Intracratonic Setting, Tartulla Field, Cooper Basin. A Seminar Presented by Tina Hughes, Santos LTD (QLD Branch Luncheon Technical Meeting January 27, 2000).

Krusi, H. R; and Idiagbor, C; 1994: Stratigraphic Traps in Eastern Niger Delta-Inventory and concepts. NAPE Bulletin, Vol. 9/01 (Nov., 1994). P. 76 - 85.S

Leeder, M. R; 2001: Sedimentology and Sedimentary Basins: From Turbulence to Tectonics; p. 258 - 529; Blackwell Science, Boston.

Mitchum R. M; Jr; P. R. Vail, and J. B. Sangree; 1977: Seismic Stratigraphy and Global

Changes of Sea levels, Part 6: Stratigraphic Interpretation of Seismic Reflection Patterns in Depositional Sequences; In: Payton, C. E; ed; Seismic Stratigraphy - Applications to Hydrocarbon Exploration: AAPG Memoir 26, P. $117-133$.

Mitchum, R. M; J. B. Sangree, P. R. Vail and W. W. Wornardt; 1992: Recognising Sequences and Systems tracts from Well Logs, Seismic Data, and Biostratigraphy: Examples from the late Cenozoic of the Gulf of Northern North Sea. Marine and Petroleum Geology: Vol. 9, P. 289 - 301.

Mulholland, 2003: Sequence/Seismic Biostratigraphy. In: Giwa et al; 2003: Emerging Trends in the application of biostratigraphy to Petroleum Exploration and Production.

NAPE; 2003. P. $1-20$.

Oboh - Ikuenobe, F. E; Obi, C. G; and Jaramillo, C. A; 2005: Lithofacies, Palynofacies, and Sequence Stratigraphy of Paleogene Strata in Southeastern Nigeria. Elsevier Ltd; Journal of African Earth Sciences, 41 (2005); P. $79-101$.

Pulham, A, J; 1993: Variations in Slope Deposition, Pliocene - Pleistocene, Offshore Louisiana, Northeast Gulf of Mexico, In: P. Weimer and H. W. Posamentier, eds; Siliciclastic Sequence Stratigraphy: AAPG Memoir 58, P. $199-233$.

Shaffer, B. L; 1987: The Potential of calcareous nanno-fossils for recognizing Plio-Pliestocene Climatic Cycles and Sequence boundaries on the shelf: Gulf Coast Societies of Sedimentary Paleontologists and Mineralogists Foundaion, Eight Annual Research Conference, P. 142 - 145.

Snedden, J. W; Thompson, L. B; Fearn, L. B; Rodgers, B. K; Maxwell, G. S; Nieto, J. A; Sleele, L. E; Wright, F. M; Okonkwo, A. A. O; Babayemi, T; Fadase, A. O; and Schoenewald, D. D; 1994: Depositional and sequence 
stratigraphic model, IYI Reservoir, Biafra member, Oso Field, Nigeria. AAPG Bulletin, Vol. 9/01 (No. 1994); P. $29-45$.

Stacher, P; 1995: Present understanding of the Niger Delta Hydrocarbon Habitat; In: Oti, M. N; and Postma, G. (Eds); Geology of Deltas: Rotterdam, A. A. Balkerna, P. $257-267$.

Stacher, P. O; Ozumba, B; and Ehoche, P; 1993: Reviewed Chrono- and Sequence Stratigraphic Chart - Niger Delta. Shell Petroleum Dev. Company (Nig.) Ltd; XGSW/I; P. $1-8$.

Vail, P. R; 1987: Seismic Stratigraphy interpretation Procedure, In Bally, A. W; ed; Atlas of Seismic Stratigraphy, Vol. I. AAPG Studies in Geology 27, P. $1-10$.

Vail, P. R; and Wornardt, W. W; 1991: An integrated approach to exploration and development in the 90's: Well log-Seismic Sequence analysis. Gulf Coast Association of Geological Societies Transactions, XLI, P. 630 650 .

Villamil, T; Claudia, A; Weimer, P; Waterman, A; Rowan, M. G; Varnai, P; Pulham, A. J; and Crews, J. R; 1998 : Biostratigraphic techniques for analyzing benthic biofacies, stratigraphic condensation, and key surface identification, Pliocene and Pleistocene Sediments, Northern Green Canyon and Ewing Bank (Offshore Louisiana), Northern Gulf of Mexico., AAPG Bulletin, V. 82, No. 5B (May, 1998 part B); P. 961 - 985.

Walker, R. G. and Plint, A. G; 1992: Wave- and Storm-dominated Shallow Marine Systems. In: Facies Models. (Eds.): Walker, R. G; and James, N; P.219-238. Toronto: Geological Association of Canada, P. 409.

Weimer, R. W; Ashley, G. M. and Sheridan, R. E; 1993: Seismic Stratigraphic Evidence for a Submerged Middle Wisconsin Barrier: Implications for Sea-level History. Geology, 21, P. 109 - 112.

Zaitlin, B. A; Dairympie, R. W. and Boyd, R; 1994: The Stratigraphic Organization of Incised-Valley Systems associated with Relative Sea-Level Change. In: Dairympie, R. W; Boyd, R. and Zaitlin, B. A; (eds). IncisedValley Systems: Origin and Sedimentary Sequences. Special Publication Society of Economic Paleontologists and Mineralogists; 51, P. $45-60$. 